\title{
Neurochemistry of Neurochemicals: Messengers of Brain Functions
}

Md. Sahab Uddin ${ }^{1, *}$, Abdullah Al Mamun${ }^{1}$, Md. Tanvir Kabir², Md. Nasrullah³, Ferdous Wahid $^{4}$, Mst. Marium Begum ${ }^{5}$, Zubair Khalid Labu ${ }^{6}$, Md. Sohanur Rahman ${ }^{7}$, Md. Tanjir $^{2}$ Islam ${ }^{8}$, Md. Shah Amran ${ }^{9}$ and Mohamed M. Abdel-Daim ${ }^{10}$

${ }^{1}$ Department of Pharmacy, Southeast University, Dhaka, Bangladesh

${ }^{2}$ Department of Pharmacy, BRAC University, Dhaka, Bangladesh

${ }^{3}$ Department of Biochemistry, King Abdulaziz University, Jeddah, Saudi Arabia

${ }^{4}$ Department of Pharmacy, University of Development Alternative, Dhaka, Bangladesh

${ }^{5}$ Department of Pharmacy, East West University, Dhaka, Bangladesh

${ }^{6}$ Department of Pharmacy, World University of Bangladesh, Dhaka, Bangladesh

${ }^{7}$ Graduate School of Innovative Life Science, University of Toyama, Toyama, Japan

${ }^{8}$ Department of Pharmacology and Clinical Pharmacy, North South University, Dhaka, Bangladesh

${ }^{9}$ Department of Pharmaceutical Chemistry, Faculty of Pharmacy, University of Dhaka, Dhaka, Bangladesh

${ }^{10}$ Pharmacology Department, Faculty of Veterinary Medicine, Suez Canal University, Ismailia, Egypt

\begin{abstract}
Neurochemistry refers to the chemical processes that occur in the brain and nervous system. This section of study determines how neurochemicals influence the network of neural operation. The brain transfers numerous chemical information via neurons to communicate. The main role of neurochemistry activities takes place in the brain, which allows it to perform numerous actions. Foundation of brain is a little bit different from man to man and several things can play a role in the levels of various neurotransmitters in the brain. It is supposed that differences in brain chemistry may accountable for a variety of behavioral disorders. A particular cell called neurons is the basis of brain. Neurotransmitters have the capability that it can trigger when ordered to do so, along with receptors for specific neurotransmitters. By sending messages with neurotransmitters to signal various cell activities, brain perform its functions. Neurotransmitter spreads chemical messages from neuron to neuron to broadcast certain work and thus it works. A neuron may accept many chemical messages, both positive and negative from the other neurons contiguous it. They are accountable to get the neuron to reply in different ways, or they may work combine to produce a certain effect. Since all of this occurs just within a split second, the neurotransmitter must be cleared away rapidly so that the same receptors can be activated again and again. Psychoactive drugs work by briefly influencing a man's neurochemistry, which thusly causes changes in a man's mind-set, cognition, perception and behavior. Neuropeptides are endogenous protein molecules that are utilized for neuronal signaling. These molecules exert more prolonged and diverse effects on behavior than neurotransmitters. Therefore the objective of this appraisal is to show study of the brain's chemical makeup especially neurotransmitters, psychopharmaceuticals, neuropeptides and their activities to nervous tissue.
\end{abstract}

Keywords: Neurochemistry, Neurochemicals, Messengers, Neurotransmitters, Psychopharmaceuticals, Neuropeptides, Brain Functions.

\section{INTRODUCTION}

Neurochemistry is the study of neurochemicals, including neurotransmitters and other molecules such as psychopharmaceuticals and neuropeptides that influence the function of neurons [1]. This special branch considers the impact of neurochemicals to the operation of neurons, synapses and neural networks. Neurochemistry enables the brain to work with the use of chemicals known as neurotransmitters [2]. Neurochemistry varies individual to individual which

*Address correspondence to this author at the Department of Pharmacy, Southeast University, Dhaka, Bangladesh; Tel: +880 1710220110/ 1670760546; E-mail: msu-neuropharma@hotmail.com, msu_neuropharma@hotmail.com owing the variations of the neurotransmitters. Different environmental incidents can actively influence the levels of neurotransmitters and their receptors in the brain, as can factors like diet, medications and various drugs. Few chemical compounds and drugs have long term affects. In pregnancy, nursing, and mother-infant attachment neurochemicals have roles which cannot be ignored [3]. Dopamine which is a specific type of neurotransmitter found to be heavily interrelated with nicotine [4]. These can cause behavioral malfunctions in the way brain works, for example individuals who smoke create addiction to compounds like cigarettes because of the path in which nicotine changes brain chemistry. Neurotransmitters actively regulated various 
organic compounds in the nervous system and their activities in different biological processes [5].

In brain these chemicals are formed and through blood circulation these neurochemicals are transported within the brain [6]. For maintaining various events within the nervous system these chemicals required specific enzymatic action, metabolism, neural communication and other mechanisms. Any changes of electrophysiological activity of neurochemicals can be responsible for changing in the brain and behavioral conditions [7]. Neurons are used by the neurotransmitter for exchanging electro-chemical signals within the brain and thus help to make communication with other organs of body [8]. Neurochemicals are responsible for performing different cognitive, physical and mental performance, such as sleep cycle, pain response and our mental activities [9].

Neurotransmitters play a vital role in controlling the transmission of messages across the synapses to the receptors [10]. Neurotransmitters can have an inhibitory, or slowing down effect or an excitatory, or speeding up effect [11]. Neurotransmitters are imperative for memory, learning and behavior among other things. Factors such as foods affect these chemicals actions. Specific receptors on the postsynaptic membrane are the binding site for neurotransmitters [12]. There are various sorts of receptors for various neurotransmitters. This alteration in the electrical state of the postsynaptic cell may either excitatory or inhibitory. The action can be influenced by glial cells, which eliminate neurotransmitters from the synaptic cleft $[13,14]$.

Neuropeptides are also known as messenger molecules that carry message between neurons in the brain $[15,16]$. In the mammalian brain, there are different neuropeptides. Hypothalamus is one of the main organs in body that discharge these chemicals and some are secreted into the blood, with peripheral outcomes as endocrine hormones [17]. Oxytocin neurons are good model system for revealing important aspects of many neuronal functions, comprising neuropeptide release. Peptides are more potent than other neurotransmitters. They need tiny amounts to yield an effect [18]. Peptides hormones found in neural tissue act as neurotransmitters and control numerous functions. For example, gastrin, that stimulates hydrochloric acid and intestinal motility [19]. Receptors in digestive tract and other neuropeptides are responsible for digestions [20]. Oxytocin and vasopressin are produced in the hypothalamus with receptors situated primarily in the brain. They have been connected with the memory and with the development of social attachments [21].

The research suggests that insufficiency, imbalances, and malfunctioning of neurotransmitters is extremely common in our society and they are accountable for numerous health complications, because when neurotransmitters are not dynamic appropriately then the mind and body do not connect effectively [22]. At the point when communication breakdowns, then organ systems don't function as they should. This outcome in an assortment of undesirable side effects both physically and mentally. The numbers of people suffering from some form of neurotransmitter imbalance are increasing [23]. Various factors for example, stress, diet, genetics and disclosure to toxins such as alcohol and nicotine are liable for this imbalance. This imbalance may progress thoughtful mental health complaints. It is observed that serotonin $(5-\mathrm{HT})$ is linked with depression and anxiety disorders for example obsessive-compulsive disorder [24]. Norepinephrine may responsible for disease like schizophrenia, while too little can cause depressive symptoms [25].

To comprehend the chemistry of brain and the nervous system is one of the most complex dares for modern science. The human brain contains about 100 billion neurons and it has been estimated that these neurons form close to 10000 billion synapses. Therefore, the intention of this appraisal is to show the neurochemistry of chemical messengers predominantly neurotransmitters, psychopharmaceuticals, neuropeptides and their brain functions.

\section{NEUROTRANSMITTERS}

Neurotransmitters or chemical messengers are endogenous chemicals which allow neurotransmission [26]. They transfer signals over a chemical synapse, for example, a neuromuscular junction, starting with one neuron then onto the next target neuron, muscle cell, or gland cell [27]. Receptors of the target cells predominantly receive the neurotransmitters, which are released in synapses into the synaptic cleft from the synaptic vesicles [28]. Amino acids are the precursors which are required to synthesize neurotransmitters. These amino acids are abundantly found in the diet and require only few biosynthetic steps to be converted to neurotransmitters. In general, on daily basis, neurotransmitters play crucial roles in a wide range of 
physiological processes and to maintain homeostasis [29]. The exact number of neurotransmitters are still unknown, however over 100 chemical messengers have been exclusively identified [26].

\section{Classes of Neurotransmitters}

Although neurotransmitters can be generally classified into two categories: excitatory and inhibitory [30], however some neurotransmitters are designated as both. In most of the cases, neurotransmitters directly activate one or more types of receptors. The effects on the postsynaptic cells are largely dependent on the properties of the receptors. Predominantly, most of the significant receptors have excitatory effects and these effects are largely dependent on some neurotransmitters like glutamate which upsurge the probability of the target cell to fire an action potential. On the other hand, for neurotransmitters like $\mathrm{Y}$ aminobutyric acid (GABA), the main receptors all have inhibitory effects. In contrast, some neurotransmitters including acetylcholine can bind with both excitatory and inhibitory receptors. However, there are certain types of receptors that stimulate complex metabolic pathways in the postsynaptic cell to exert effects that cannot specifically be referred either as excitatory or inhibitory [27-33].

\section{Excitatory Neurotransmitters}

Excitatory neurotransmitters are also denoted as "on switches" of the nervous system, since they increase the probability of nerve cells to produce an action potential [31]. Excitatory neurotransmitters stimulate the excitability of cells by directly opening the ion channels including glutamate or by signal transduction pathways. These neurotransmitters play key role in maintaining body's most important and basic functions like, body's responses in emergency conditions, thinking processes, motor movement and critical thinking [32]. Physiologically, excitatory neurotransmitters including acetylcholine, epinephrine, norepinephrine, dopamine, histamine and glutamate help to uphold body's stimulatory effects like enhanced alertness, energy, and activity [26].

\section{Inhibitory Neurotransmitters}

Conversely, inhibitory neurotransmitters are also called as the "off switches" of the nervous system, due to their ability to decrease the likelihood of nerve cells to fire an action potential [34]. In general, excitatory effects must be balanced with inhibitory effects in brain to ensure it is properly functioning. If excitatory effects predominate then effects like irritability, insomnia, restlessness and even seizures can be observed. Inhibitory system of the body can be compared with the brakes on a car, which slows down the excitatory system or effects. The inhibitory neurotransmitters are also referred as the body's natural tranquilizers due to their effects in inducing sleep, diminish aggression and promote calmness. Common examples of inhibitory neurotransmitters are dopamine, GABA, taurine, acetylcholine, glycine and 5-HT [26].

From the chemical point of view neurotransmitters are monoamines, amino acids and peptides. There are two main groups of neurotransmitters: classical neurotransmitters (Table 1 ) that are synthesized in the nerve terminals and neuropeptides stated later [34].

\section{Mechanism of Neurotransmitters}

In general, neurotransmitters are stored in a synapse in synaptic vesicles located at the presynaptic side of the synapse [35]. The neurotransmitters must need to cross the synaptic cleft to bind with the target receptors located in the membrane on the postsynaptic side of the synapse [36]. Most of the neurotransmitters are about the size of a single amino acid. Nevertheless, there are also some neurotransmitters which are as large as proteins or peptides [37]. Typically, a released neurotransmitter stays in the synaptic cleft for a shorter period of time before being metabolized by the enzymes, reuptake into the presynaptic neuron or bound to a postsynaptic receptor [38]. However, these short-term exposures are generally adequate to trigger a postsynaptic response achieved through synaptic transmission [39].

A neurotransmitter can be released at the presynaptic terminal either in response to a threshold or graded electrical potential and low level "baseline" release also can also take place well without electrical stimulation [40]. Ultimately, the released neurotransmitter then move through the synapse to be recognized and to be bound with the receptors of postsynaptic neurons. This binding can either lead to inhibitory or excitatory effects. It is believed that the neurons are well connected to many more neurons and these neurons can fire if altogether the excitatory effects are greater than those of inhibitory effects. Eventually, it will generate a new action potential at its axon hillock to release neurotransmitters and to pass on to another neighboring neuron [41]. 
Table 1: A Number of Classical Neurotransmitters and their Precursors [34]

\begin{tabular}{|c|c|c|}
\hline System & Transmitter & Precursor \\
\hline Cholinergic & Acetylcholine & Choline + Acetylcoenzym A \\
\hline \multirow[t]{5}{*}{ Aminoacidergic } & GABA & Glucose $\rightarrow$ Glutamate \\
\hline & Aspartic acid & Glucose + Glutamine; Glutamate \\
\hline & Glutamic Acid & Glucose + Glutamine; Aspartate \\
\hline & Glycine & Serine \\
\hline & Homocysteine & Cysteine $\rightarrow$ Cystine \\
\hline \multicolumn{3}{|l|}{ Monoaminergic } \\
\hline \multirow[t]{3}{*}{ Catecholamines } & Dopamine & Tyrosine $\rightarrow$ Dihydroxyphenylalanine $\rightarrow$ Dopamine \\
\hline & Norepinephrine & Norepinephrine $\rightarrow$ Epinephrine \\
\hline & Epinephrine & - \\
\hline \multirow[t]{2}{*}{ Indolamines } & Tryptamine & - \\
\hline & $5-\mathrm{HT}$ & Tryptophan $\rightarrow$ 5-Hydroxytryptophan \\
\hline \multirow[t]{2}{*}{ Others, related to amino acid } & Histamine & Histidine \\
\hline & Taurine & Cysteine $\rightarrow$ Cysteamine \\
\hline \multirow[t]{4}{*}{ Purinergic } & Adenosine & - \\
\hline & $\begin{array}{l}\text { Adenosine } \\
\text { diphosphate }\end{array}$ & - \\
\hline & Adenosine monophosphate & - \\
\hline & Adenosine triphosphate & - \\
\hline
\end{tabular}

\section{Brain Neurotransmitter Systems}

Certain types of neurotransmitters expressed by the neurons occasionally form distinct systems. Activation these systems affect large volumes of the brain which is known as volume transmission [42]. Most important neurotransmitter systems comprise the dopamine system, the cholinergic system, the noradrenaline system, the 5-HT system, etc. Throughout the brain, trace amines, predominantly through trace amineassociated receptor 1 (TAAR1) activation, have a substantial effect on neurotransmission in monoamine pathways $[43,44]$. A brief comparison of these systems is represented in Table 2.

\section{Neurotransmitters Imbalance}

Scientifically, there are no recognized norms for appropriate levels or balances of different neurotransmitters. In most cases at any given time, it is practically impossible to estimate levels of neurotransmitters in a brain or body. Neurotransmitters are found to control each other's release and the regulation of neurotransmitter release is crucial to maintain normal physiological processes and to stay healthy [54-58]. Whereas, many neurological diseases and disorders including Parkinson's disease (PD), insomnia, depression, ADHD, memory loss, anxiety, addictions, dramatic changes in weight and addictions may take place due to the imbalances in neurotransmitter systems [59]. Various factors including chronic physical or emotional distress, genetics and certain types of medications are the major contributors to changes in neurotransmitter system [60]. Table 3 represents the disorders linked with the imbalance of neurotransmitters.

\section{PSYCHOACTIVE DRUGS}

Chemical substances which can cause alterations in consciousness, perception, or mood are known as psychoactive drug, psychotropic or psychopharmaceutical [91]. These chemical substances can be used for recreational purpose (legally or illegally) or purposefully to alter individual's consciousness, or for ritual, spiritual purposes as entheogens (i.e. any psychoactive substance that induces a spiritual experience). Some psychoactive drugs containing therapeutic values are also prescribed by physicians and other associated health care professionals $[92,93]$. Examples of these psychoactive drugs include analgesics, anticonvulsant, anesthetics, 
Table 2: Neurotransmitter Systems in the Brain [33,45-53]

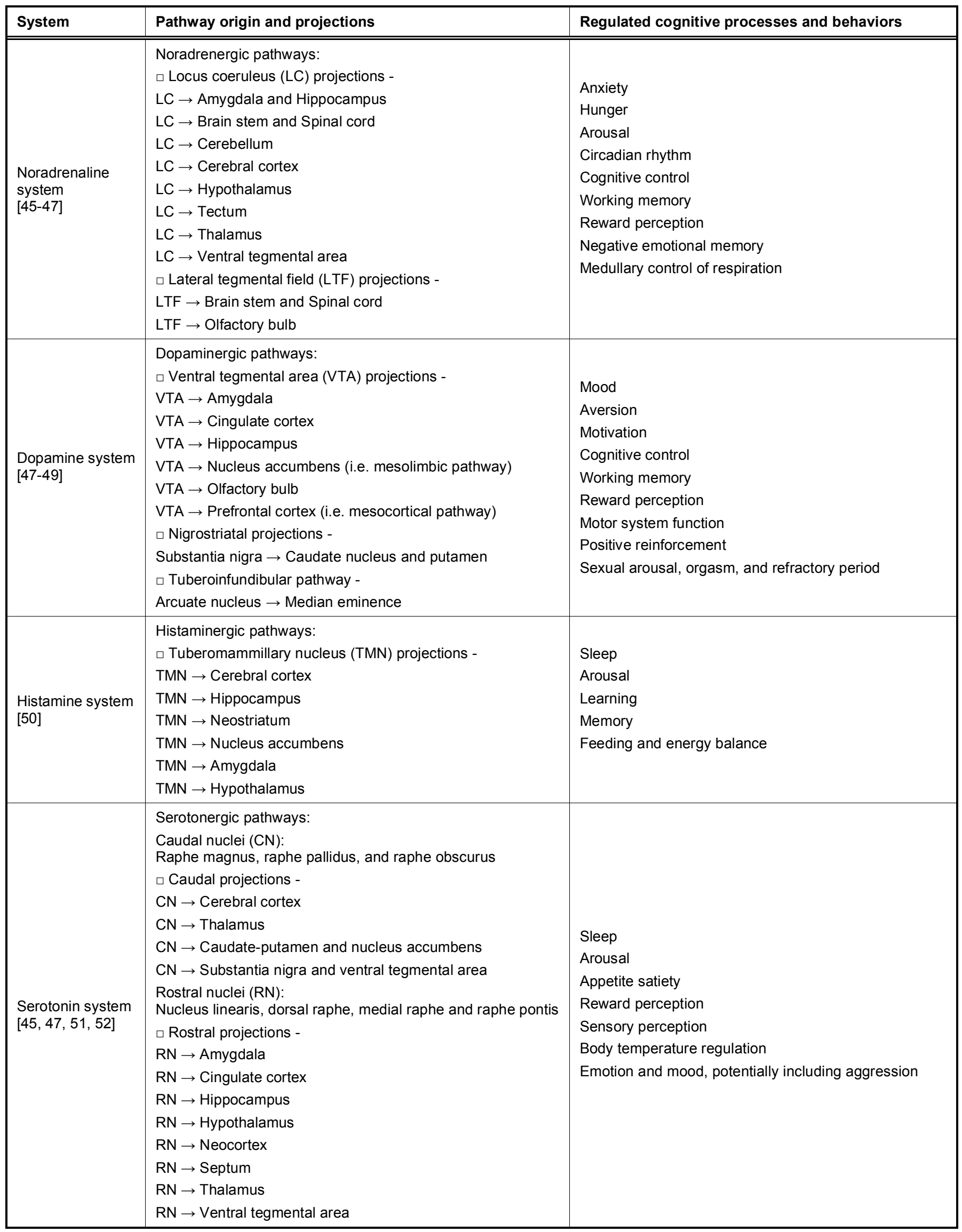


(Table 2). Continued.

\begin{tabular}{|c|c|c|}
\hline System & Pathway origin and projections & Regulated cognitive processes and behaviors \\
\hline $\begin{array}{l}\text { Acetylcholine } \\
\text { system } \\
{[45,47,53]}\end{array}$ & $\begin{array}{l}\text { Cholinergic pathways: } \\
\text { Forebrain cholinergic nuclei (FCN): } \\
\text { Nucleus basalis of Meynert (nbM), medial septal nucleus and } \\
\text { diagonal band } \\
\square \text { Forebrain nuclei projections - } \\
\text { FCN } \rightarrow \text { Hippocampus } \\
\text { FCN } \rightarrow \text { Cerebral cortex } \\
\text { FCN } \rightarrow \text { Limbic cortex and sensory cortex } \\
\text { Brainstem cholinergic nuclei (BCN): } \\
\text { Pedunculopontine nucleus, laterodorsal tegmentum, medial } \\
\text { habenula and } \\
\text { parabigeminal nucleus } \\
\square \text { Brainstem nuclei projections - } \\
\text { BCN } \rightarrow \text { Ventral tegmental area } \\
\text { BCN } \rightarrow \text { Thalamus }\end{array}$ & $\begin{array}{l}\text { Arousal } \\
\text { Emotion } \\
\text { Learning } \\
\text { Reward perception } \\
\text { Short-term memory } \\
\text { Motor system function }\end{array}$ \\
\hline
\end{tabular}

Table 3: Neurotransmitter Imbalance and Associated Disorders [61-90]

\begin{tabular}{|c|c|}
\hline Disorder & Pathophysiology \\
\hline $\begin{array}{l}\text { Alzheimer's disease } \\
\text { (AD) [61-63] }\end{array}$ & $\begin{array}{l}\text { Extracellular } \beta \text {-amyloid pledges, intracellular neurofibrillary tangles and senile plaques, predominantly in the limbic } \\
\text { system (e.g. hippocampus), in the association area of the cortex and in neurons that synthesize and use } \\
\text { acetylcholine (e.g., in the nbM and its wide projections to the cortex). }\end{array}$ \\
\hline Anxiety [64-66] & $\begin{array}{l}\text { Imbalance of endogenous inhibitors and stimulators of the GABA receptor may result in reduced activity of GABA. } \\
\text { Additionally, these inhibitors and stimulators may also trigger imbalances in norepinephrine and 5-HT responses. }\end{array}$ \\
\hline Autism [67-68] & $\begin{array}{l}\text { Possible hyperserotonemia, which is accountable for } 30 \text { to } 50 \% \text { of autistic people, with no proof of central } 5 \text { - } \mathrm{HT} \\
\text { abnormalities. }\end{array}$ \\
\hline Brain injury $[69,70]$ & $\begin{array}{l}\text { Neuronal death may take place due to the injuries (e.g. prolonged seizures, hypoxia, trauma) stimulating excessive } \\
\text { secretion of excitatory neurotransmitters (e.g. glutamate) and buildup of intracellular calcium ion }\left(\mathrm{Ca}^{++}\right) \text {. }\end{array}$ \\
\hline Depression $[71,72]$ & $\begin{array}{l}\text { Critical aberrations in cholinergic, catecholaminergic (i.e. noradrenergic, dopaminergic) and } 5-\mathrm{HT} \text { transmission } \\
\text { possible association of other hormones and neuropeptides (e.g. substance } \mathrm{P} \text {, dopamine, acetylcholine, GABA). }\end{array}$ \\
\hline $\begin{array}{l}\text { Seizure disorders }[73, \\
74]\end{array}$ & $\begin{array}{l}\text { Increased activity of glutamate or reduced activity of GABA can cause seizures comprising of abrupt synchronous } \\
\text { high-frequency firing by localized groups of neurons in certain brain areas. }\end{array}$ \\
\hline $\begin{array}{l}\text { Huntington's disease } \\
{[75,76]}\end{array}$ & $\begin{array}{l}\text { Major neuronal injury in the cortex and striatum owing to polyglutamine expansion (i.e. encoded by CAG repeat), } \\
\text { generated by an atypical gene on chromosome } 4 \text { (i.e. the anomalous gene overproduces the protein huntingtin, } \\
\text { which may cartel with molecules that persuade extreme stimulation of cells by excitatory amino acid } \\
\text { neurotransmitters such as glutamate). }\end{array}$ \\
\hline Mania $[77,78]$ & $\begin{array}{l}\text { Increased norepinephrine and dopamine action, abridged 5-HT levels and anomalous glutamate } \\
\text { neurotransmission. }\end{array}$ \\
\hline $\begin{array}{l}\text { Neuroleptic malignant } \\
\text { syndrome }[79,80]\end{array}$ & $\begin{array}{l}\text { Muscle rigidity, change in mental status fever and autonomic instability can take place due to the blockage of } \\
\text { dopamine (D2) receptors by drugs (e.g. antipsychotic drugs, methylphenidate) or due to the sudden withdrawal of } \\
\text { a dopaminergic agonist. }\end{array}$ \\
\hline Pain $[81,82]$ & $\begin{array}{l}\text { Tissue injury can trigger secretion of glutamate and substance P in the posterior horn of the spinal cord. } \\
\text { Furthermore, this tissue injury can also cause release of other macromolecules including bradykinin, neurokinin A } \\
\text { and calcitonin gene-related protein (i.e. located mainly in the lamina II and IV of the spinal cord) that mediate pain } \\
\text { gestures. } \\
\text { Further inflection of these gestures by endorphins (i.e. in the spinal cord) and by 5-HT and norepinephrine (i.e. in } \\
\text { the descending pathways that originate in the brain). }\end{array}$ \\
\hline Parkinsonism $[83,84]$ & Blockage of dopaminergic receptors by antipsychotic drugs can cause inhibition of the dopaminergic system. \\
\hline PD $[85,86]$ & $\begin{array}{l}\text { Alteration of the dopamine/acetylcholine balance and the subsequent striatal acetylcholine over activity are often to } \\
\text { be involved with the loss of dopaminergic neurons of the pars compacta in the substantia nigra and other areas, } \\
\text { with decreased levels of dopamine and metenkephalin. }\end{array}$ \\
\hline Schizophrenia $[87,88]$ & $\begin{array}{l}\text { Increased presynaptic discharge, synthesis of dopamine, sensitivity or density of postsynaptic D2 receptors, or a } \\
\text { combination. }\end{array}$ \\
\hline $\begin{array}{l}\text { Tardive dyskinesia }[89, \\
90]\end{array}$ & Hypersensitive D2 receptors owing to prolonged blockade by antipsychotic drugs. \\
\hline
\end{tabular}


Table 4: Psychoactive Drugs and their Primary Neurotransmitter or Receptor and Mode of Action [101-120]

\begin{tabular}{|c|c|c|}
\hline $\begin{array}{l}\text { Neurotransmitter or } \\
\text { Receptor }\end{array}$ & Mode of Action & Examples \\
\hline \multirow[t]{3}{*}{$\begin{array}{l}\text { Acetylcholine } \\
{[101,102]}\end{array}$} & $\begin{array}{l}\text { Acetylcholine receptor agonists } \\
\text { (i.e. cholinergics) }\end{array}$ & Arecoline, nicotine, piracetam \\
\hline & $\begin{array}{l}\text { Acetylcholine receptor } \\
\text { antagonists (i.e. muscarinic } \\
\text { antagonists) }\end{array}$ & $\begin{array}{l}\text { Scopolamine, benzatropine, dimenhydrinate, diphenhydramine, doxylamine, } \\
\text { atropine, quetiapine, olanzapine, most tricyclics }\end{array}$ \\
\hline & $\begin{array}{l}\text { Acetylcholine receptor } \\
\text { antagonists (i.e. nicotinic } \\
\text { antagonists) }\end{array}$ & Memantine, bupropion \\
\hline $\begin{array}{l}\text { Adenosine } \\
\text { [103] }\end{array}$ & Adenosine receptor antagonists & Caffeine, theobromine, theophylline \\
\hline \multirow[t]{5}{*}{$\begin{array}{l}\text { Dopamine } \\
\text { [104] }\end{array}$} & Dopamine reuptake inhibitors & $\begin{array}{l}\text { Cocaine, bupropion, methylphenidate, certain TAAR1 agonists like } \\
\text { amphetamine, phenethylamine, and methamphetamine }\end{array}$ \\
\hline & Dopamine releasers & $\begin{array}{l}\text { Cavendish bananas, TAAR } 1 \text { agonists like amphetamine, phenethylamine and } \\
\text { methamphetamine }\end{array}$ \\
\hline & D2 receptor agonists & Pramipexole, ropinirole, L-3,4-Dihydroxyphenylalanine, memantine \\
\hline & D2 receptor antagonists & $\begin{array}{l}\text { Haloperidol, droperidol, many antipsychotics (e.g. risperidone, olanzapine, } \\
\text { quetiapine) }\end{array}$ \\
\hline & D2 receptor partial agonists & Lysergic acid diethylamide (LSD), aripiprazole \\
\hline \multirow{3}{*}{$\begin{array}{l}\text { GABA } \\
{[105]}\end{array}$} & GABA reuptake inhibitors & Tiagabine, vigabatrin, deramciclane \\
\hline & GABA receptor agonists & $\begin{array}{l}\text { Ethanol, niacin, barbiturates, diazepam, clonazepam, lorazepam, temazepam, } \\
\text { alprazolam and other benzodiazepines, zolpidem, eszopiclone, zaleplon and } \\
\text { other nonbenzodiazepines, muscimol }\end{array}$ \\
\hline & GABA receptor antagonists & Thujone, bicuculline \\
\hline \multirow[t]{4}{*}{$\begin{array}{l}\text { Norepinephrine } \\
{[106]}\end{array}$} & $\begin{array}{l}\text { Norepinephrine reuptake } \\
\text { inhibitors }\end{array}$ & $\begin{array}{l}\text { Most non-selective serotonin reuptake inhibitors (SSRIs) antidepressants such } \\
\text { as amoxapine, atomoxetine, bupropion, venlafaxine, quetiapine, tricyclics, } \\
\text { methylphenidate, serotonin and norepinephrine reuptake inhibitors (SNRIs) } \\
\text { such as duloxetine, venlafaxine, cocaine, tramadol and certain TAAR1 } \\
\text { agonists like amphetamine, phenethylamine, methamphetamine. }\end{array}$ \\
\hline & Norepinephrine releasers & $\begin{array}{l}\text { Ephedrine, pseudoephedrine, amphetamine, phenethylamine, } \\
\text { methamphetamine }\end{array}$ \\
\hline & $\begin{array}{l}\text { Norepinephrine receptor } \\
\text { agonists }\end{array}$ & Clonidine, guanfacine, phenylephrine \\
\hline & $\begin{array}{l}\text { Norepinephrine receptor } \\
\text { antagonists }\end{array}$ & $\begin{array}{l}\text { Carvedilol, metoprolol, mianserin, prazosin, propranolol, trazodone, yohimbine, } \\
\text { olanzapine }\end{array}$ \\
\hline \multirow{4}{*}{$\begin{array}{l}\text { Serotonin } \\
{[107]}\end{array}$} & Selective 5-HT receptor agonists & Methylphenidate, LSD, psilocybin, mescaline \\
\hline & 5-HT reuptake inhibitors & $\begin{array}{l}\text { Most antidepressants including tricyclics such as imipramine, SSRIs such as } \\
\text { fluoxetine, sertraline and citalopram, and SNRIs such as duloxetine and } \\
\text { venlafaxine, cocaine, tramadol, and certain TAAR1 agonists like amphetamine, } \\
\text { tryptamine, and methamphetamine }\end{array}$ \\
\hline & 5 - $\mathrm{HT}$ releasers & Fenfluramine, 3,4-Methylenedioxymethamphetamine (MDMA), tryptamine \\
\hline & 5-HT receptor antagonists & $\begin{array}{l}\text { Ritanserin, mirtazapine, mianserin, trazodone, cyproheptadine, memantine, } \\
\text { atypical antipsychotics (e.g. risperidone, olanzapine, quetiapine) }\end{array}$ \\
\hline \multirow{2}{*}{$\begin{array}{l}\text { a-amino-3-hydroxy-5- } \\
\text { methyl-4- } \\
\text { isoxazolepropionic acid } \\
\text { (AMPA) receptor } \\
\text { [108] }\end{array}$} & $\begin{array}{l}\text { a-amino-3-hydroxy-5-methyl-4- } \\
\text { isoxazolepropionic acid (AMPA) } \\
\text { receptor positive allosteric } \\
\text { modulators }\end{array}$ & Aniracetam, piracetam \\
\hline & AMPA receptor antagonists & Kynurenic acid, topiramate \\
\hline \multirow[t]{2}{*}{$\begin{array}{l}\text { Cannabinoid receptor } \\
\text { [109] }\end{array}$} & $\begin{array}{l}\text { Cannabinoid receptor partial } \\
\text { agonists }\end{array}$ & Anandamide, cannabidiol, cannabinol \\
\hline & $\begin{array}{l}\text { Cannabinoid receptor inverse } \\
\text { agonists }\end{array}$ & Rimonabant \\
\hline
\end{tabular}


(Table 4). Continued.

\begin{tabular}{|c|c|c|}
\hline $\begin{array}{l}\text { Neurotransmitter or } \\
\text { Receptor }\end{array}$ & Mode of Action & Examples \\
\hline $\begin{array}{l}\text { Fatty acid amide } \\
\text { hydrolase inhibitors } \\
\text { [110] }\end{array}$ & $\begin{array}{l}\text { Methoxy arachidonyl } \\
\text { fluorophosphonate, } \mathrm{N} \text { - } \\
\text { arachidonylglycine }\end{array}$ & - \\
\hline $\begin{array}{l}\text { Melanocortin receptor } \\
\text { [111] }\end{array}$ & Melanocortin receptor agonists & Bremelanotide \\
\hline $\begin{array}{l}\text { NMDA receptor } \\
\text { [112] }\end{array}$ & NMDA receptor antagonists & $\begin{array}{l}\text { Ethanol, ketamine, Nitrous oxide, glutamate, memantine (used for moderate to } \\
\text { severe AD) }\end{array}$ \\
\hline $\begin{array}{l}\text { Y-hydroxybutyrate } \\
\text { (GHB) receptor } \\
{[113]}\end{array}$ & GHB receptor agonists & GHB, amisulpride, trans-4-hydroxycrotonic acid \\
\hline $\begin{array}{l}\text { Sigma receptor } \\
\text { [114] }\end{array}$ & Sigma-1 receptor agonists & Cocaine, fluvoxamine, ibogaine, opipramol \\
\hline \multirow{6}{*}{$\begin{array}{l}\text { Opioid receptor } \\
\text { [115] }\end{array}$} & $\mu$-opioid receptor agonists & Morphine, heroin, oxycodone, codeine \\
\hline & $\mu$-opioid receptor partial agonists & Buprenorphine \\
\hline & $\begin{array}{l}\mu \text {-opioid receptor inverse } \\
\text { agonists }\end{array}$ & Naloxone \\
\hline & $\mu$-opioid receptor antagonists & Naltrexone \\
\hline & $\mathrm{K}$-opioid receptor agonists & Butorphanol, nalbuphine, pentazocine, ibogaine \\
\hline & K-opioid receptor antagonists & Buprenorphine \\
\hline $\begin{array}{l}\text { Histamine receptor } \\
\text { [116] }\end{array}$ & $\begin{array}{l}\mathrm{H}_{1} \text { histamine receptor } \\
\text { antagonists }\end{array}$ & $\begin{array}{l}\text { Diphenhydramine, doxylamine, mirtazapine, mianserin, quetiapine, olanzapine, } \\
\text { meclozine, dimenhydrinate, most tricyclics }\end{array}$ \\
\hline $\begin{array}{l}\text { Monoamine oxidase } \\
\text { [117] }\end{array}$ & Monoamine oxidase inhibitors & $\begin{array}{l}\text { Phenelzine, iproniazid, tranylcypromine, selegiline, rasagiline, moclobemide, } \\
\text { isocarboxazid, linezolid, benmoxin }\end{array}$ \\
\hline $\begin{array}{l}\text { Melatonin receptor } \\
\text { [118] }\end{array}$ & Melatonin receptor agonists & Ramelteon \\
\hline $\begin{array}{l}\text { Imidazoline receptor } \\
\text { [119] }\end{array}$ & Imidazoline receptor agonists & Apraclonidine, clonidine, moxonidine, rilmenidine \\
\hline $\begin{array}{l}\text { Orexin receptor } \\
\text { [120] }\end{array}$ & Orexin receptor agonists & Modafinil \\
\hline
\end{tabular}

hormonal preparations and antiparkinson medication or drugs such as anxiolytic and hypnotic drugs which are used to treat neuropsychiatric disorders. Certain psychoactive substances are also used in the detoxification purposes and in the rehabilitation programs for psychotropic drug users [94].

\section{Neurochemistry of Psychoactive Drugs}

Alterations in a person's cognition, perception, mood and behavior can be temporarily triggered by psychoactive drugs [95]. In many ways psychoactive drugs can stimulate these changes by affecting the brain. In the brain, these drugs particularly act on one or more neurotransmitter or on neuroreceptor and the drugs which increase the activity of these systems are known as agonists. In case of neurotransmitters, these agents increase their synthesis and also by reducing their reuptake from the synapses and by simulating the action by directly binding to the postsynaptic receptors [96]. In contrast, drugs that decrease the activity of the neurotransmitters are called as antagonists and they act by altering the synthesis or by blocking postsynaptic receptors, as a result binding of the neurotransmitters will be inhibited [97].

Structure and functions of the neurons can also be changed due to the exposure to a psychoactive substance. These structural and functional changes are generated by the nervous system to re-establish the homeostasis which is disrupted by the presence of these psychoactive drugs. Exposure to an antagonist for a certain neurotransmitter can upsurge the number of receptors for that particular neurotransmitter. Furthermore the receptors themselves may also 
become more responsive to neurotransmitters; this phenomenon is known as sensitization [98]. On the contrary, there is also a process known as desensitization or tolerance, which involves overstimulation of certain receptors for a specific neurotransmitter or reduction in numbers these receptors and their sensitivity. Although sensitization and desensitization processes are likely to place with chronic exposure, they may also take place just after a single exposure. These processes are believed to take part in drug dependence and addiction [99]. Physical dependence on antidepressants or anxiolytics may lead to anxiety or worsen depression and these are most common withdrawal symptoms of these agents.

It should be noted that many drugs act on more than one transmitter or receptor in the brain [100]. In the Table 4 a brief of notable drugs and their main neurotransmitter or receptor and method of action is presented.

\section{NEUROPEPTIDES}

Neuropeptides are small protein-like molecules that are synthesized in the cell body and for neuronal communication [121]. These are involved with various brain functions, including learning and memory, analgesia, food intake, social behaviors, metabolism and reproduction $[122,123]$. The basic differences between neuropeptide and peptide hormone are the cell types that secrete and respond to the molecule. Neuropeptides are primarily secreted from neuronal cells and signal to neighboring neurons. Whereas, neuroendocrine cells mainly secrete peptide hormones and following secretion they travel via the blood to distant target tissues to induce a response [124]. Prohormone convertases and carboxypeptidases are same set of enzymes that synthesize both neuropeptides and peptide hormones. These enzymes selectively cut the peptide precursor at particular processing sites to produce the bioactive peptides

Table 5: Bioactive Peptides and their Alliance [34]

\begin{tabular}{|c|c|}
\hline Bioactive Peptide & Group \\
\hline Substance $\mathrm{P}$, substance $\mathrm{K}$ (tachykinins) & \multirow[t]{5}{*}{ Brain and gastrointestinal peptides } \\
\hline Neurotensin & \\
\hline Cholecystokinin & \\
\hline Gastrin & \\
\hline Bombesin & \\
\hline Galanin & \multirow[t]{4}{*}{ Neuronal } \\
\hline Neuromedin K & \\
\hline Neuropeptidey & \\
\hline Peptide YY & \\
\hline Cortikotropin releasing hormone & \multirow[t]{5}{*}{ Hypothalamic releasing factors } \\
\hline Growth hormone releasing hormone & \\
\hline Gonadotropin releasing hormone & \\
\hline Somatostatin & \\
\hline Thyrotropin releasing hormone & \\
\hline Adrenocorticotropic hormone & \multirow[t]{5}{*}{ Pituitary hormones } \\
\hline Growth hormone & \\
\hline Prolactin & \\
\hline Lutenizing hormone & \\
\hline Thyrotropin & \\
\hline Oxytocin & \multirow[t]{2}{*}{ Neurohypophyseal peptides } \\
\hline Vasopressin & \\
\hline Atrial natriuretic peptide & \multirow[t]{2}{*}{ Neuronal and endocrine } \\
\hline Vasoactive intestinal peptide & \\
\hline Enkephalines (met-, leu-) & Opiate peptides \\
\hline
\end{tabular}


[125]. The associations of the bioactive peptides are presented in Table $\mathbf{5}$.

\section{Neurochemistry of Neuropeptides}

Neuropeptides control communications of neurons by acting on cell surface receptors and these neuropeptides sometimes co-released with various small-molecule neurotransmitters [126]. Precursors of neuropeptides are encoded by the human genome that comprises about 90 genes. Currently, in the mammalian brain, 100 different peptides are found to be released by different populations of neurons [127]. Peptides, neurotransmitters and gasotransmitters are the common signals that neurons use in different neuronal communication. Unlike various conventional neurotransmitters, once secreted peptides are not recycled back into the cell and they are distinctive amongst these cell to cell signaling molecules in several ways [128]. Additional difference is that after release, peptides are changed by extracellular peptidases. Sometimes these extracellular cleavages deactivate the biological activity. Instead in some cases, the extracellular cleavages upsurge the affinity of a peptide for a particular receptor while reducing its affinity for another receptor [129]. A list of neuroactive peptides coexisting with other neurotransmitters is given in Table 6.

Many populations of neurons have distinctive biochemical phenotypes [130]. For example, in one subpopulation of about 3000 neurons in the arcuate nucleus of the hypothalamus, three anorectic peptides are co-expressed: $\alpha$-melanocyte-stimulating hormone ( $\alpha-M S H)$, galanin-like peptide and cocaine-andamphetamine-regulated transcript (CART) and in another subpopulation two orexigenic peptides are coexpressed, neuropeptide $Y$ and agouti-related peptide (AGRP) [129]. It has been found that different populations of neurons contain distinct biochemical phenotypes [130]. For example, in one subpopulation of about 3000 neurons in the arcuate nucleus of the hypothalamus, 3 anorectic peptides are co-expressed: galanin-like peptide, $\alpha$-melanocyte-stimulating hormone and CART and in another subpopulation 2 orexigenic peptides are co-expressed such as AGRP and neuropeptide $Y$ [129]. However, in addition to these peptides in the arcuate nucleus, dynorphin, galanin, $\beta$ endorphin, ghrelin, encephalin, neurotensin, somatostatin, growth-hormone releasing hormone and neuromedin $U$ are also found to be expressed in subpopulations of arcuate neurons [131]. All of these peptides are secreted centrally and act on other neurons at specific receptors. The neuropeptide $Y$ neurons likewise make the conventional inhibitory neurotransmitter GABA.

Information processing mediated by peptide signals is different from conventional neurotransmitters and many of them act in different ways for example, as stated earlier oxytocin and vasopressin have prominent and explicit effects on social behavior's including maternal behavior and bonding with the child [132, 133].

Table 6: Neuroactive Peptides and its Coexistent with other Neurotransmitters [129]

\begin{tabular}{|l|l|}
\hline Neuroactive Peptides & Coexisting Neurotransmitters \\
\hline \hline Norepinephrine & $\begin{array}{l}\text { Galanin } \\
\text { Enkephalin } \\
\text { Neuropeptide } Y\end{array}$ \\
\hline GABA & $\begin{array}{l}\text { Somatostatin } \\
\text { Cholecystokinin } \\
\text { Neuropeptide } Y\end{array}$ \\
\hline Acetylcholine & $\begin{array}{l}\text { Vasoactive intestinal peptide } \\
\text { Substance P }\end{array}$ \\
\hline Dopamine & $\begin{array}{l}\text { Cholecystokinin } \\
\text { Neurotensin } \\
\text { Glucagon-like peptide-1 }\end{array}$ \\
\hline Epinephrine & Neuropeptide Y \\
& Neurotensin \\
\hline 5-HT & $\begin{array}{l}\text { Substance P } \\
\text { Thyrotropin-releasing hormone } \\
\text { Enkephalin }\end{array}$ \\
\hline
\end{tabular}




\section{CONCLUSION}

The brain is outfitted with diversity of molecules that enable neurons to communicate with each other. The fact that one can read this text, remember what has been read and even breathe during the entire time that these events take place relies on the amazing chemistry that occurs in the brain and the nerve cells with which it communicates. Life in the human body is tortuous. Everything is necessary for our survival that makes us feel happy. Our brain has self-produced neurochemicals that turn the pursuits and struggles of life into pleasure and make us feel happy when we achieve them. Apt neuronal communication is obligatory for typical existent.

\section{ABBREVIATIONS}

$\begin{array}{ll}5-\mathrm{HT} & =\text { Serotonin } \\ \mathrm{D} 2 & =\text { Dopamine } \\ \mathrm{GABA} & =\text { Y-aminobutyric acid } \\ \text { TAAR1 } & =\text { Trace amine-associated receptor } 1 \\ \mathrm{LC} & =\text { Locus coeruleus } \\ \mathrm{LTF} & =\text { Lateral tegmental field } \\ \mathrm{VTA} & =\text { Ventral tegmental area } \\ \mathrm{TMN} & =\text { Tuberomammillary nucleus } \\ \mathrm{CN} & =\text { Caudal nuclei } \\ \mathrm{RN} & =\text { Rostral nuclei } \\ \mathrm{FCN} & =\text { Forebrain cholinergic nuclei } \\ \mathrm{BCN} & =\text { Brainstem cholinergic nuclei } \\ \mathrm{nbM} & =\text { Nucleus basalis of Meynert } \\ \mathrm{PD} & =\text { Parkinson's disease } \\ \mathrm{AD} & =\text { Alzheimer's disease } \\ \mathrm{LSD} & =\text { Lysergic acid diethylamide } \\ \mathrm{SSRI} & =\text { Selective serotonin reuptake inhibitor } \\ \mathrm{SNRIS} & =\text { Serotonin and norepinephrine reuptake } \\ & \text { inhibitors }\end{array}$

MDMA = 3,4-Methylenedioxymethamphetamine
AMPA $=\alpha$-amino-3-hydroxy-5-methyl-4- isoxazolepropionic acid
GHB = $y$-hydroxybutyrate
CART = Cocaine-and-amphetamine-regulated transcript
AGRP = Agouti-related peptide

\section{AUTHORS' CONTRIBUTIONS}

This work was carried out in collaboration between all authors. Author MSU designed the study, wrote the protocol, managed the analyses of the study and prepared the draft of the manuscript. Authors MSU, AAM, MTK, MN, FW, MMB, MSR and MTI managed the literature searches and participated in manuscript preparation. Authors ZKL, MMAD and MSA reviewed the scientific contents of the manuscript. All the authors read and approved the final manuscript.

\section{ACKNOWLEDGEMENTS}

The authors wish to thank the anonymous reviewer(s)/editor(s) of this article for their constructive reviews. The authors are also grateful to the Department of Pharmacy, Southeast University, Dhaka, Bangladesh.

\section{COMPETING INTERESTS}

The authors proclaim that they have no competing interests.

\section{REFERENCES}

[1] Siegel GJ, Albers RW, Brady ST and Price DL. Basic Neurochemistry. 7th Ed. Academic Press; 2006.

[2] Benedetti F, Mayberg HS, Wager TD, Stohler CS and Zubieta J. Neurobiological Mechanisms of the Placebo Effect. J Neurosci 2005; 25(45): 10390-10402.

[3] Magon $\mathrm{N}$ and Kalra S. The orgasmic history of oxytocin: Love, lust, and labor. Indian J Endocrinol Metab 2011; 15(I3): S156-S161. https://doi.org/10.4103/2230-8210.84851

[4] Benowitz NL. Nicotine Addiction. N Engl J Med 2010; 362(24): 2295-2303. https://doi.org/10.1056/NEJMra0809890

[5] Shawn C. Burdette and Stephen J. Lippard. Meeting of the minds: Metalloneurochemistry. Proc Natl Acad Sci 2003; 100(7): 3605-3610

[6] Zeepedia. Neurological basis of bahaviour. [cited 2017 July 25]: Available from: http://www.zeepedia.com/ read.php\%3Fbasic_neurochemistry_neurochemicals_neuro modulator_synaptic_cleft_neurological_basis_of_bahaviour\% 26b\%3D92\%26c\%3D30

[7] Shulera ML and Hickman JJ. Toward in vitro models of brain structure and function. Proc Natl Acad Sci 2014; 111(38): 13682-13683. 
[8] Upadhyay RK. Transendothelial transport and its role in therapeutics. Int Sch Res Notices 2014; 1-39.

[9] Lindquist KA, Wager TD, Kober $H$, Bliss-Moreau $E$ and Barrett LF. The brain basis of emotion: A meta-analytic review. Behav Brain Sci 2012; 35: 121-202.

https://doi.org/10.1017/S0140525X11000446

[10] Steinle JJ and Smith PG. Presynaptic Muscarinic Facilitation of Parasympathetic Neurotransmission after Sympathectomy in the Rat Choroid. J Pharmacol Exp Ther 2000; 294(2): 627632.

[11] Boettigera A, Ermentroutb B and Oster G. The neural origins of shell structure and pattern in aquatic mollusks. Proc Natl Acad Sci 2009; 106(16): 6837- 6842.

[12] Pekka A, Postila, Vattulainen I and Róg T. Selective effect of cell membrane on synaptic neurotransmission. Sci Rep 2016; 6(19345): 1-10.

[13] Diamond JS. Deriving the Glutamate Clearance Time Course from Transporter Currents in CA1 Hippocampal Astrocytes: Transmitter Uptake Gets Faster during Development. J Neurosci 2005; 25(11): 2906-2916.

[14] Chaturvedi R, Reddig K and Li H. Long-distance mechanism of neurotransmitter recycling mediated by glial network facilitates visual function in Drosophila. Proc Natl Acad Sci 2014; 111(7): 2812-2817.

[15] van Golen FA, Li KW, de Lange RPJ, Jespersen S and Geraerts WPM. Mutually exclusive neuronal expression of peptides encoded by the FMRFa gene underlies a differential control of copulation in Lymnaea. J Biol Chem 1995; 270: 28487-28493.

[16] Adamson KJ, Wang T, Zhao M, Bell F, Kuballa AV and Storey KB. Molecular insights into land snail neuropeptides through transcriptome and comparative gene analysis. BMC Genomics 2015; 16(308): 1-15.

[17] Ludwig, M. Are neuropeptides brain hormones? [cited 2017 July 25]: Available from: http://sbmsintranet.bms.ed.ac.uk/ sources/Briefings/Ludwig $\% 20 \% 20$ Are $\% 20$ Neuropeptides $\% 2$ 0Brain\%20Hormones.pdf

[18] Chang $C$, Chiang $C$ and Jackson MB. Fusion pores and their control of neurotransmitter and hormone release. J Gen Physiol 2017; 149(2): 1-22.

[19] Gabriel AMS. Taste receptors in the gastrointestinal system. Flavour 2015; 4(14): 1-4.

[20] Begg DP and Woods SC. The endocrinology of food intake. Nat Rev Endocrinol 2013; 9: 584-597.

[21] Baribeau DA and Anagnostou E. Oxytocin and vasopressin: linking pituitary neuropeptides and their receptors to social neurocircuits. Front Neurosci 2015; 9: 335.

[22] Vaváková $M$, Ďuračková $Z$ and Trebatická J. Markers of oxidative stress and neuroprogression in depression disorder. Oxid Med Cell Longev 2015; 1-12. https://doi.org/10.3389/fnins.2015.00335

[23] Holistichelp.net. Neurotransmitters and your health. [cited 2017 July 25]: Available from: http://www.holistichelp.net/ neurotransmitters.html

[24] Rao TSS, Asha MR, Ramesh BN and Rao KSJ. Understanding nutrition, depression and mental illnesses. Indian J Psychiatry 2008; 50(2): 77-82.

[25] Arnsten AFT. Catecholamine and second messenger influences on prefrontal cortical networks of "Representational Knowledge": A rational bridge between genetics and the symptoms of mental illness. Cerebral Cortex 2007; 17(1): i6-i15.

[26] Ayano G. Common neurotransmitters: Criteria for neurotransmitters, key locations, classifications and functions. Adv Psyc Neur 2016; 1(1): 1-5.

[27] Lodish H, Berk A and Zipursky SL. Molecular cell biology: Neurotransmitters, synapses, and impulse transmission. 4th ed. W. H. Freeman; 2000.
[28] Masson J, Sagné C, Hamon M and Mestikawy SE. Neurotransmitter transporters in the central nervous system. Pharmacol Rev 1999; 51(3): 439-464.

[29] Uddin MS, Mamun AA, Sarwar MS, Chaity NH, Haque A, Akter $\mathrm{N}$, et al. Medicine that causes memory loss: Risk of neurocognitive disorders. Int Neuropsy Dis Journal 2016; 8(1): 1-18.

https://doi.org/10.9734/INDJ/2016/26317

[30] Hori $\mathrm{K}$ and Hoshino M. GABAergic neuron specification in the spinal cord, the cerebellum, and the cochlear nucleus. Neural Plast; 2012(2012): 1-11.

[31] Richards CD. Anaesthetic modulation of synaptic transmission in the mammalian CNS. Br J Anaesth 2002; 89(1): 79-90.

[32] Steimer T. The biology of fear- and anxiety-related behaviors. Dialogues Clin Neurosci 2002; 4(3): 231-249.

[33] Wikipedia. Neurotransmitter. [cited 2017 July 25]: Available from: https://en.wikipedia.org/wiki/Neurotransmitter

[34] Psych.lf1.cuni.cz. Neurochemistry. [cited 2017 July 25]: Available from: http://psych.If1.cuni.cz/bpen/neurochemistry. htm

[35] Lodish H, Berk A, Zipursky SL, Matsudaira P, Baltimore D and Darnell J. Molecular Cell Biology. 4th ed. W. H. Freeman; 2000.

[36] Elias L and Saucier D. Neuropsychology: Clinical and experimental foundations. Pearson; 2005.

[37] Purves D, Augustine GJ, Fitzpatrick D, Katz LC, LaMantia A and McNamara JO. Neuroscience, 2nd ed. Sunderland (MA): Sinauer Associates; 2001.

[38] Gordan R, Gwathmey JK and Xie L. Autonomic and endocrine control of cardiovascular function. World $\mathrm{J}$ Cardiol 2015; 7(4): 204-214.

https://doi.org/10.4330/wjc.v7.i4.204

[39] Newkirk GS, Hoon M, Wong RO and Detwiler PB. Inhibitory inputs tune the light response properties of dopaminergic amacrine cells in mouse retina. J Neurophysiol 2013; 110(2): 536-552.

[40] Shyu B and Vogt BA. Short-term synaptic plasticity in the nociceptive thalamic-anterior cingulate pathway. Mol Pain 2009; 5(51): 1-20.

[41] Diwakar S, Lombardo P, Solinas S, Naldi G and Angelo ED. Local field potential modeling predicts dense activation in cerebellar granule cells clusters under Itp and Itd control. PLoS One 2011; 6(7): e21928.

[42] Syková E and Nicholson C. Diffusion in brain extracellular space. Physiol Rev 2008; 88(4): 1277-1340.

[43] Miller GM. The emerging role of trace amine-associated receptor 1 in the functional regulation of monoamine transporters and dopaminergic activity. J Neurochem 2011; 116(2): 164-176.

https://doi.org/10.4330/wjc.v7.i4.204

[44] Eiden, L.E. and Weihe E. "VMAT2: a dynamic regulator of brain monoaminergic neuronal function interacting with drugs of abuse". Ann N Y Acad Sci 2011; 1216: 86-98.

[45] Malenka RC, Nestler EJ and Hyman SE. Widely projecting systems: Monoamines, acetylcholine, and orexin. In: Sydor A and Brown RY, editors. Molecular neuropharmacology: A foundation for clinical neuroscience. 2nd ed. McGraw-Hill Medical 2009; p. 155.

[46] Brunton L, Bruce A. Chabner BA, Knollman B. Goodman and Gilman's the pharmacological basis of therapeutics. 12 th ed. New York: Mc Graw Hill; 2011.

[47] Rang HP. Pharmacology. 5th ed. Edinburgh: Churchill Livingstone; 2003.

[48] Malenka RC, Nestler EJ and Hyman SE. Widely projecting systems: Monoamines, acetylcholine, and orexin. In: Sydor A and Brown RY, editors. Molecular neuropharmacology: A 
foundation for clinical neuroscience. 2nd ed. McGraw-Hill Medical 2009; p. 147-148.

[49] Calipari ES, Bagot RC, Purushothaman I, Davidson TJ, Yorgason JT and Peña CJ. In vivo imaging identifies temporal signature of D1 and D2 medium spiny neurons in cocaine reward. Proc Natl Acad Sci USA 2016; 113: 272631.

[50] Malenka RC, Nestler EJ and Hyman SE. Widely projecting systems: Monoamines, acetylcholine, and orexin. In: Sydor A and Brown RY, editors. Molecular neuropharmacology: A foundation for clinical neuroscience. 2nd ed. McGraw-Hill Medical 2009; p. 175-176.

[51] Malenka RC, Nestler EJ and Hyman SE. Widely projecting systems: Monoamines, acetylcholine, and orexin. In: Sydor A and Brown RY, editors. Molecular neuropharmacology: A foundation for clinical neuroscience. 2nd ed. McGraw-Hill Medical 2009; p. 158-160.

[52] Ayano G. Common neurotransmitters: Criteria for neurotransmitters, key locations, classifications and functions. Adv Psy Neur 2016; 1(1): 1-5.

[53] Uddin MS, Haque A, Mamun AA, Iqbal MA, Kabir MT, Rony RK, et al. Searching the linkage between high fat diet and Alzheimer's disease: A debatable proof stand for ketogenic diet to alleviate symptoms of Alzheimer's patient with APOE $\varepsilon 4$ allele. J Neur Neurophy 2016; 7(5): 1-9. https://doi.org/10.4172/2155-9562.1000397

[54] Netter P. Biochemical variables in the study of temperament. In: Strelau J and Angleitner A, editors. Explorations in temperament: International perspectives on theory and measurement. Plenum Press 1991; p. 147-161.

[55] Trofimova I, Robbins TW. Temperament and arousal systems: a new synthesis of differential psychology and functional neurochemistry. Neurosci Biobehav Rev 2016; 64: 382-402.

[56] Cloninger CR, Svrakic DM and Przybeck TR. A psychobiological model of temperament and character. Arch Gen Psychiatry 1993; 50: 975-990.

[57] Trofimova IN. The interlocking between functional aspects of activities and a neurochemical model of adult temperament. In: Arnold MC, editor. Temperaments: Individual differences, social and environmental influences and impact on quality of life. Nova Science Publishers Inc.2016; p. 77-147.

[58] Depue RA, Morrone-Strupinsky JV. A neurobehavioural model of affiliate bonding: implications for conceptualizing a human trait of affiliation. J Behav Brain Sci 2005; 28(3): 313350

[59] Valenzuela CF, Puglia MP, Zucca S. Focus on: Neurotransmitter systems. Alcohol Res Heal 2011; 34(1): 106-120.

[60] Ferguson JM. SSRI antidepressant medications: Adverse effects and tolerability. Primary Care Companion to the Journal of Clinical Psychiatry 2001; 3(1): 22-27.

[61] Uddin MS. Alzheimer's disease and you: Can Alzheimer's abduct consciousness? J Neurol Disorders 2017; 5(5): 1-2. https://doi.org/10.4172/2329-6895.1000e123

[62] Uddin MS, Nasrullah M, Hossain MS, Rahman MM, Sarwar MS, Amran MS, et al. Evaluation of nootropic activity of Persicaria flaccida on cognitive performance, brain antioxidant markers and acetylcholinesterase activity in rats: Implication for the management of Alzheimer's disease. Am J Psy Neuroscience 2016; 4(2): 26-37.

https://doi.org/10.11648/j.ajpn.20160402.12

[63] Uddin MS, Mamun AA, Hossain MS, Akter F, Iqbal MA and Asaduzzaman M. Exploring the effect of Phyllanthus emblica L. on cognitive performance, brain antioxidant markers and acetylcholinesterase activity in rats: Promising natural gift for the mitigation of Alzheimer's disease. Ann Neurosci 2016; 23(4): 218-229.

https://doi.org/10.1159/000449482
[64] Bystritsky A, Khalsa SS, Cameron ME and Schiffman J. Current diagnosis and treatment of anxiety disorders. Pharm Therapeut 2013; 38(1): 30-38, 41-44, 57.

[65] Kimiskidis VK and Valeta T. Epilepsy and anxiety: Epidemiology, classification, aetiology, and treatment. Epilep Disorders 2012; 14(3): 248-256.

[66] Uddin MS and Amran MS. Pharmakon comprehensive pharmaceutical pharmacology. 1st Ed. Bangladesh: Krishnachura Prokashoni; 2014.

[67] Compart PJ. The pathophysiology of autism. Glob Adv Health Med 2013; 2(6): 32-37.

[68] Meier SM, Petersen L, Schendel DE, Mattheisen $M$, Mortensen PB and Mors O. Obsessive-compulsive disorder and autism spectrum disorders: Longitudinal and offspring risk. PLoS One 2015; 10(11): e0141703.

https://doi.org/10.1371/journal.pone.0141703

[69] Werner $\mathrm{C}$ and Engelhard K. Pathophysiology of traumatic brain injury. Br J Anaesth 2007; 99(1): 4-9.

[70] Algattas $\mathrm{H}$ and Huang $\mathrm{JH}$. Traumatic brain injury pathophysiology and treatments: Early, intermediate, and late phases post-injury. Int J Mol Sci 2014; 15(1): 309-341.

[71] Gold PW, Machado-Vieira R and Pavlatou MG. Clinical and biochemical manifestations of depression: relation to the neurobiology of stress. Neural Plast 2015; 2015(2015): 1-11.

[72] Hepgul N, Cattaneo A, Zunszain PA and Pariante CM. Depression pathogenesis and treatment: What can we learn from blood mRNA expression? BMC Medicine 2013; 11(28): 1-13.

[73] Moritz ML and Ayus JC. The pathophysiology and treatment of hyponatraemic encephalopathy: An update. Nephrol Dial Transplant 2003; 18(12): 2486-2491.

[74] Shakirullah NA, Khan A and Nabi M. The prevalence, incidence and etiology of epilepsy. Int J Clin Exp Neurol 2014; 2(2): 29-39.

https://doi.org/10.1111/j.0924-2708.2004.00085.x

[75] Paulsen JS. Cognitive impairment in huntington disease: Diagnosis and treatment. Curr Neurol Neurosci Rep 2011; 11(5): 474-483.

[76] Choudhary S, Kumar P and Malik J. Plants and phytochemicals for Huntington's disease. Pharmacognosy Reviews 2013; 7(14): 81-91.

[77] Fountoulakis KN, Vieta E, Siamouli M, Valenti M, Magiria S, Oral $\mathrm{T}$, et al. Treatment of bipolar disorder: a complex treatment for a multi-faceted disorder. Ann Gen Psychiatry 2007; 6(27); 1-12.

[78] Hilty DM, Leamon MH, Lim RF, Kelly RH and Hales RE. A review of bipolar disorder in adults. Psychiatry (Edgmont) 2006; 3(9): 43-55.

[79] Ananth J, Aduri K, Parameswaran S and Gunatilake S Neuroleptic malignant syndrome: risk factors, pathophysiology, and treatment. Acta Neuropsychiatr 2004; 16(4): $219-228$

https://doi.org/10.1111/10.1111/j.0924-2708.2004.00085.x

[80] Behan WMH, Madigan M, Clark BJ, Goldberg J and McLellan $\mathrm{DR}$. Muscle changes in the neuroleptic malignant syndrome. J Clin Pathol 2000; 53: 223-227.

[81] Stucky CL, Gold MS and Zhang X. Mechanisms of pain. Proc Natl Acad Sci USA 2001; 98(21): 11845-11846.

[82] Helms JE and Barone CP. Physiology and treatment of pain Crit Care Nurse 2008; 28(6): 38-49.

[83] Racette BA, Esper GJ, Antenor J, Black KJ, Burkey A, Moerlein SM, et al. Pathophysiology of parkinsonism due to hydrocephalus. J Neurol Neurosurg Psychiatry 2004; 75: 1617-1619.

[84] Davie CA. A review of Parkinson's disease. Br Med Bull 2008; 86(1): 109-127. 
[85] Guridi J, González-Redondo R and Obeso JA. Clinical features, pathophysiology, and treatment of levodopainduced dyskinesias in Parkinson's disease. Parkinsons Dis 2012; 2012: 943159.

[86] Jenner P. Treatment of the later stages of Parkinson's disease- pharmacological approaches now and in the future. Transl Neurodegener 2015; 4(3): 1-9.

[87] Adams C, Wilson P, Gilbody S, Bagnall A and Lewis R. Drug treatments for schizophrenia. Qual Health Care 2000; 9(73)79.

[88] Lakhan SE and Vieira KF. Schizophrenia pathophysiology: are we any closer to a complete model? Ann Gen Psychiatry 2009; 8(12): 1-8. https://doi.org/10.1186/1744-859X-8-12

[89] Waln $O$ and Jankovic J. An update on tardive dyskinesia: from phenomenology to treatment. Tremor Other Hyperkinet Mov (NY) 2013; 3: tre-03-161-4138-1.

[90] Nelson LA, McGuire JM and Hausafus SN. Melatonin for the treatment of tardive dyskinesia. Ann Pharmacother 2003; 37: 1128-31.

[91] Gould TJ. Addiction and cognition. Addict Sci Clin Pract 2010; 5(2): 4-14.

[92] Fox TP, Oliver G and Ellis SM. The destructive capacity of drug abuse: An overview exploring the harmful potential of drug abuse both to the individual and to society. Int Sch Res Notices; 2013(2013): 1-6.

[93] Lee J, Kresina TF, Campopiano M, Lubran R and Clark HW. Use of pharmacotherapies in the treatment of alcohol use disorders and opioid dependence in primary care. Biomed Res Int 2015; 2015: 137020.

[94] Blum K, Han D, Femino J, Smith DE, Saunders S, et al. Systematic evaluation of compliance to prescribed treatment medications and abstinence from psychoactive drug abuse in chemical dependence programs: Data from the comprehensive analysis of reported drugs. PLoS One 2014; 9(9): e104275. https://doi.org/10.1371/journal.pone.0104275

[95] Opalach C, Romaszko J, Jaracz M, Kuchta R, Borkowska A and Buciński A. Coping styles and alcohol dependence among homeless people. PLoS One 2016; 11(9): e0162381.

[96] Hisahara $S$ and Shimohama S. Dopamine receptors and Parkinson's disease. Int J Med Chem 2011; 2011(2011): 116.

[97] Crockett MJ and Fehr E. Social brains on drugs: tools for neuromodulation in social neuroscience. Soc Cogn Affect Neurosci 2014; 9(2): 250-254.

[98] Berman DE, Hazvi S, Neduva $V$ and Dudai $Y$. The role of identified neurotransmitter systems in the response of insular cortex to unfamiliar taste: Activation of ERK1-2 and formation of a memory trace. J Neurosci 2000; 20(18): 70177023.

[99] Malty RH, Hudmon A, Fehrenbacher JC and Vasko MR. Long-term exposure to PGE2 causes homologous desensitization of receptor-mediated activation of protein kinase A. J Neuroinflammation 2016; 13(181): 1-17.

[100] Lüscher $C$ and Ungless MA. The mechanistic classification of addictive drugs. PLoS Medicine 2006; 3(11): e437.

[101] Uddin MS, Mamun AA, Hossain MS, Ashaduzzaman M, Noor MAA, Hossain MS, et al. Neuroprotective effect of Phyllanthus acidus $\mathrm{L}$. on learning and memory impairment in scopolamine-induced animal model of dementia and oxidative stress: Natural wonder for regulating the development and progression of Alzheimer's disease. Adv Alzheimer Dis 2016; 5(2):53-72.

http://dx.doi.org/10.4236/aad.2016.52005

[102] Wikipedia. Psychoactive drug. [cited 2017 July 25]: Available from: https://en.wikipedia.org/wiki/Psychoactive_drug
[103] Marsha F. Clinical toxicology. Caffeine and related nonprescription sympathomimetics. Philadelphia: Saunders; 2001.

[104] Kazuki K and Hiroyuki S. High content of dopamine, a strong antioxidant, in cavendish banana. J Agric Food Chem 2000; 48(3): 844-8.

[105] Penberthy WT and Saul AW. Supplements accelerate benzodiazepine withdrawal a case report and biochemical rationale. [cited 2017 July 25]: Available from: http://orthomolecular.org/resources/omns/v10n09.shtml

[106] Di Carlo G, Borrelli F, Ernst E and Izzo AA. St John's wort: Prozac from the plant kingdom. Trends Pharmacol Sci 2001; 22(6): 292-7.

[107] Berumen LC, Rodríguez A, Miledi R and García-Alcocer G. Serotonin receptors in hippocampus. ScientificWorldJournal 2012; 2012(2012): 1-15.

[108] Prieto ML and Wollmuth LP. Gating modes in AMPA receptors. J Neurosci 2010; 30(12): 4449-4459.

[109] Pertwee RG. Inhibitors of the enzymic hydrolysis of endocannabinoids. [cited 2017 July 25]: Available from: http://www.tocris.com/pdfs/cannabinoid_receptor_review/pag e_011.html

[110] Ahn K, Johnson DS and Cravatt BF. Fatty acid amide hydrolase as a potential therapeutic target for the treatment of pain and CNS disorders. Expert Opin Drug Discov 2009; 4(7): 763-784. https://doi.org/10.1517/17460440903018857

[111] Kim CS, Lee S, Kim RY, Kim B, Li S, Lee IH, et al. Identification of domains directing specificity of coupling to Gproteins for the melanocortin MC3 and MC4 receptors. J Biol Chem 2002; 277( 35): 31310-31317.

[112] Bettini E, Sava A, Griffante C, Carignani C, Buson A, Capelli $\mathrm{AM}$, et al. Identification and characterization of novel NMDA receptor antagonists selective for NR2A- over NR2Bcontaining receptors. J Pharmacol Exp Ther 2010; 335(3): 636-644.

[113] Connelly WM, Errington AC and Crunelli V. y-Hydroxybutyric acid (GHB) is not an agonist of extrasynaptic GABAA receptors. PLoS One 2013; 8(11): e79062. https://doi.org/10.1371/journal.pone.0079062

[114] Spitzer D, Simon Jr PO, Kashiwagi H, Xu J, Zeng C, Vangveravong $\mathrm{S}$, et al. Use of multifunctional sigma-2 receptor ligand conjugates to trigger cancer-selective cell death signaling. Cancer Res 2012; 72(1): 201-9.

[115] Glick SD and Maisonneuve IS. Mechanisms of antiaddictive actions of ibogaine. Ann N Y Acad Sci 1998; 844: 214-26.

[116] Simon FER and Simons KJ. H1 antihistamines: Current status and future directions. World Allergy Organ J 2008; 1(145): 145-155.

[117] Dhingra D and Kumar V. Evidences for the involvement of monoaminergic and GABAergic systems in antidepressantlike activity of garlic extract in mice. Indian J Pharmacol 2008; 40(4): 175-9.

[118] Dubocovich ML. Pharmacology and function of melatonin receptors. FASEB J 1998; 2(12): 2765-2773.

[119] van Zwieten PA. Central imidazoline receptors as a target for centrally acting antihypertensive drugs. Pharm World Sci 1995; 17: 186.

[120] Mieda M, Hasegawa E, Kisanuki YY, Sinton CM, Yanagisawa $M$ and Sakurai $T$. Differential roles of Orexin receptor-1 and -2 in the regulation of non-REM and REM sleep. J Neurosci 2011; 31(17): 6518-6526.

[121] Merlin NJ, Joseph T, Shaiju SD and Mathan S. Neuropeptides -A review. Asian J Pharm 2014; 4(4): 198200.

[122] Romano A, Tempesta B, Di Bonaventura MVM and Gaetani $\mathrm{S}$. From autism to eating disorders and more: The role of 
oxytocin in neuropsychiatric disorders. Front Neurosci 2016; 9(497): 1-19.

https://doi.org/10.3389/fnins.2015.00497

[123] Yan X-C, Chen Z-F, Sun J, Matsumura K, Wu RSS, et al. Transcriptomic analysis of neuropeptides and peptide hormones in the barnacle Balanus amphitrite: Evidence of roles in larval settlement. PLoS One 2012; 7(10): e46513.

[124] Nussey $S$ and Whitehead S. Endocrinology: An integrated approach. Oxford: BIOS Scientific Publishers; 2001.

[125] Southey BR, Sweedler JV and Rodriguez-Zas SL. Prediction of neuropeptide cleavage sites in insects. Bioinformatics 2008; 24(6): 815-825 https://doi.org/10.1093/bioinformatics/btn044

[126] Bakos J, Zatkova M, Bacova Z and Ostatnikova D. The role of hypothalamic neuropeptides in neurogenesis and neuritogenesis. Neural Plast 2016; 2016(2016): 1-10.

[127] Neuropeptides.nl. Neuropeptides. [cited 2017 July 25]: Available from: http://www.neuropeptides.nl/

[128] Jain SK and Zelena D. Role of ionotropic glutamate receptors in the control of prolactin secretion by other neurotransmitters and neuropeptides at the level of the pituitary. Endocr Regul 2013; 47(2): 65-74.

[129] Wikipedia. Neuropeptide. [cited 2017 July 25]: Available from: https://en.wikipedia.org/wiki/Neuropeptide\#cite_note-2

[130] Neves A, Costalat R and Pellerin L. Determinants of brain cell metabolic phenotypes and energy substrate utilization unraveled with a modeling approach. PLOS Comput Biol 2012; 8(9): e1002686.

[131] Lookformedical.com. Why are antidepressants targeting serotonin receptors? [cited 2017 July 25]: Available from: //lookformedical.com/search.php?lang=1\&q=Receptors\%2C+ G-Protein-Coupled\&src=faq

[132] Serafini G, Pompili M, Lindqvist D, Dwivedi $Y$ and Girardi $P$. The role of neuropeptides in suicidal behavior: A systematic review. Biomed Res Int 2013; 2013(2013): 1-22.

[133] Kelly AM and Goodson LJ. Hypothalamic oxytocin and vasopressin neurons exert sex-specific effects on pair bonding, gregariousness, and aggression in finches. Proc Natl Acad Sci USA 2014; 111(16): 6069-6074. https://doi.org/10.1073/pnas.1322554111

Received on 01-09-2017

Accepted on 30-09-2017

Published on 30-12-2017

DOI: https://doi.org/10.6000/2292-2598.2017.05.04.6

(C) 2017 Uddin et al.; Licensee Lifescience Global.

This is an open access article licensed under the terms of the Creative Commons Attribution Non-Commercial License (http://creativecommons.org/licenses/by-nc/3.0/) which permits unrestricted, non-commercial use, distribution and reproduction in any medium, provided the work is properly cited. 